\title{
Bank Competition and Outreach: Evidence from Turkey
}

\author{
Ahmet Faruk Aysan, Mustafa Disli, and Koen Schoors
}

\begin{abstract}
In light of the importance of banking sector outreach and given concerns that competition may adversely affect it, this study explores the empirical linkage between banking structure and outreach in Turkey for the period 1988-2010. Bank-, province-, and bank-province-level estimation results indicate that competition is in general conducive to the outreach of banks. We do not find evidence for collusive behavior among banks when they have multimarket contact. At the province level, the presence of foreign-owned banks is associated with higher outreach, while at the bank-province level, we observe that outreach of domestic banks exceeds that of foreign banks. Together, these results suggest that there are procompetitive spillover effects from foreign banks to their domestic counterparts.
\end{abstract}

KEY WORDS: bank competition, bank outreach, multimarket contact.

The liberalization and privatization policies in many countries have triggered a sharp debate in the banking literature about the virtues and vices of competition in the banking industry. Conventional theory states that perfect competition maximizes economic welfare by supplying the greatest amount of credit at the lowest price and, in turn, providing financial services to a greater share of the population (see, e.g., Guzman 2000; Pagano 1993). A competitive environment is, because of improved efficiency and cost reductions, of benefit to banking sector customers. Furthermore, in order to gain a competitive edge, increased competition may elevate the value of relationship banking, hence inducing banks to invest more in private information production (e.g., Boot and Thakor 2000; Yafeh and Yosha 2001). ${ }^{1}$ However, the pioneering work of Stiglitz and Weiss (1981) emphasizes the role of informational frictions between borrowers and lenders and shows that credit rationing can be an equilibrium outcome in competitive debt markets. Consequently, it has been claimed that some market power is needed to establish valuable relationships with clients. From this point of view, in a competitive environment, banks' investment in long-term relationships may not yield the intended economic benefits because customers will be more tempted to engage in price comparisons and bank shopping. Increased competitive pressure may therefore destabilize (traditional) durable relationships. In this

Ahmet Faruk Aysan (ahmet.aysan@boun.edu.tr) is an associate professor in the Department of Economics, Boğaziçi University, Istanbul, Turkey, and a board member of the Central Bank of the Republic of Turkey. Mustafa Disli (mustafa.disli@ugent.be), corresponding author, is a postdoctoral researcher in the Department of General Economics, Ghent University, Belgium. Koen Schoors (koen.schoors@ugent.be) is a professor in the Department of General Economics, Ghent University, Belgium, and a research fellow at the Bank of Finland, Helsinki. The authors gratefully acknowledge the helpful comments and suggestions of Ali M. Kutan (editor), Gökhan Özertan (guest editor), an anonymous referee, Milena Petrova, Alin Marius Andries, Olivier De Jonghe, Demir Ali Köse, Alexandru Minea, Koen Inghelbrecht, and the participants in the International Finance and Banking Society Conference, Valencia, June 18-20, 2012, the Globalization and Higher Education in Economics and Business Administration conference, Iasi, October 18-20, 2012, and the "Structural Issues in Emerging Market Economies" workshop at Bogaziçi University, Istanbul, January 25, 2013. 
context, competitive banking markets may be associated with less credit availability, especially to small and opaque firms (Petersen and Rajan 1995). ${ }^{2}$

In accordance with these ambiguous theoretical predictions, the empirical evidence also is not clear on the issue. For example, based on cross-country data, Beck et al. (2004) find that less-concentrated banking markets are associated with a reduction in financing obstacles, especially for smaller firms. ${ }^{3}$ In contrast, Petersen and Rajan (1995) find that younger firms in the United States receive more credit at better conditions in local markets where bank concentration is higher. In particular, attention has been given to the accommodating role of relationship banking in the intertemporal smoothing of loan terms, that is, subsidizing borrowers in earlier periods in return for a share of the rents in the future, which benefits young, informationally opaque firms. For Italy, Bonaccorsi di Patti and Dell'Ariccia (2004) find that bank competition is less favorable to the creation of new firms in sectors where informational asymmetries are particularly severe. ${ }^{4}$

While the importance of well-functioning financial intermediaries in general, and banks in particular, in raising productivity and promoting economic growth has been well documented, we still have very little knowledge concerning the outreach of financial systems and its determinants. ${ }^{5}$ Without broad access to financial services, credit constraints reduce the efficiency of resource allocation because opaque businesses will have difficulties financing (profitable) investment projects (Galor and Zeira 1993). An inclusive financial system, with extensive geographical coverage reaching out to more people, can also help reduce poverty and income disparities (Beck et al. 2007; Honohan 2004). According to Rajan and Zingales (2003), access to finance for large numbers of people expands opportunities beyond the rich and fosters efficient resource allocation and, hence, economic growth.

Although the benefits of increased access to finance are intuitively well understood, we have a less clear understanding of the impact of competition on banking sector outreach. The effect of competition on outreach could go both ways and, therefore, deserves an empirical investigation. In light of the importance of banking sector outreach and given concerns that competition can adversely affect it, this study explores the empirical linkage between banking structure and outreach in Turkey employing a long sample period from 1988 to 2010. In particular, we proceed at three levels. First, using bank level regressions, we analyze the impact of competition on diverse proxy measures of outreach: the number of provinces served, the volume of deposits, the volume of credits, and the different types of deposit accounts. Second, at the province level, we examine whether competition affects the growth rate in branch location or geographic penetration, the per capita volume of credits generated, the per capita volume of deposits placed at banks, and the different types of deposit volumes. Finally, bank-province-level regressions enable us to verify whether competition influences the probability of opening new bank branches, the per capita volume of credits granted by banks, and the per capita volume of deposits placed in a specific bank in a particular province.

In general, we find that competition improves the outreach of financial intermediaries. This finding is robust over bank-, province-, and bank-province-level regressions. Specifically, we find that competition increases the volume of loans and deposits, implying that banks are forced to work with reduced intermediation margins. We also find that multimarket competition does not trigger collusive behavior among banks as it is not associated with lower outreach figures. Concerning the impact of foreign banks on outreach, we find that their presence boosts competition and stimulates domestic banks to offer more credits and attract more deposits. 


\section{Contributions and Relation to Prior Work}

In exploring the impact of bank competition on outreach, this study contributes to the literature in a number of ways. First, to our knowledge, no prior research has specifically addressed the question of how competition may affect banking sector outreach. Previous studies have mainly focused on the relationship between banking market concentration and credit availability (e.g., Beck et al. 2004; Berger et al. 2007; DeYoung et al. 1999; Petersen and Rajan 1995) while neglecting the importance of savings as a means for empowerment and social inclusion. Although through microfinance programs much attention has been paid to addressing the credit needs of income households, increasingly, attention has shifted to the need to provide a wider range of banking services, with a particular focus on savings. In many instances, it has also been proved that the demand for savings facilities is stronger than the demand for credit (Peachey and Roe 2006). ${ }^{6}$

Second, our data set makes the distinction not only between bank access (branches and branch orientation) and use (volume of credits, volume/number of deposits) but also among different use alternatives (types of deposits). For a given bank, it would make sense to invest in an additional outlet whenever the projected gains from reductions in transaction costs and information asymmetries are at least as high as the additional investment costs. A climate of increased competition and increased pressure upon margins and profitability may affect the financial results of the branches negatively, forcing some banks to reorient themselves and adopt more cost-efficient bank practices or even leading to the outright closure of branches. This may, in turn, impair the provision of financial services to less profitable segments and regions. ${ }^{7}$ However, banks may also react to increased competitive pressure by resorting to non-price-competition strategies and try to capture a larger share of the banking market by investing more in brick and mortar to establish valuable relationships. ${ }^{8}$ Whether the net effects of competition on outreach (in terms of bank orientation and use) are positive or negative is, ultimately, an empirical question.

Third, recognizing that banks may pursue both competitive and cooperative strategies simultaneously, this paper relates to the literature on multimarket contact and collusive behavior. Innovation and deregulation have made the financial landscape increasingly turbulent, inducing banks to turn to strategic alliances to minimize costs and optimize benefits. In such an environment, it is argued that strategic alliances can be one powerful means of enhancing the competitive position of firms (Hill 1990). Furthermore, it has been suggested that the best partner in an alliance is a strong competitor (Deming 1993). In this vein, banks that meet each other in multiple points may be involved in different levels of competition than are banks with more limited contact (Bernheim and Whinston 1990; Heggestad and Rhoades 1978). ${ }^{9}$ To the best of our knowledge, this is the first paper to empirically investigate the potential impact of collusive behavior on bank outreach.

Finally, the richness of our data set allows us to explore some important additional issues, which have been hitherto largely neglected. In Turkey, as well as in most emerging economies, state-owned banks have vast and extensive branch networks and are at the core of the payment system. Rather than pursuing exclusively profit maximization, the existence of state-owned banks has been motivated based on their balancing function between social and economic objectives (see, e.g., Megginson 2005a, 2005b). ${ }^{10}$ The implied empirical question is therefore whether state-owned banks indeed exhibit better outreach outcomes.

We also explore whether foreign bank presence affects outreach outcomes. Proponents of foreign bank participation argue that these banks bring capital as well as technical 
skills, leading to a more competitive and efficient banking sector. ${ }^{11}$ However, foreign banks are often blamed for "skimming the cream" of the market by focusing mainly on large and transparent borrowers, thus leaving domestic banks with a pool of opaque businesses, which are on average more risky (Beck and Martinez Peria 2010; Detragiache et al. 2008; Mian 2006).

\section{Empirical Methodology and Data Set}

Our data set allows us to analyze the impact of the above-discussed facets on outreach at the bank level, the province level, and the bank-province level. Specifically, we conduct (1) bank panel regressions with data aggregated for each bank over all provinces and each year, (2) province panel regressions with data aggregated for each province and each year, and (3) bank-province panel regressions with data for each bank within each province and each year. ${ }^{12}$

\section{Empirical Methodology and Variables}

We investigate the bank-level outreach by running the following specification:

$$
Y_{i, t}=\alpha_{i}+\alpha_{t}+\alpha_{1} H H I_{i, t-1}+\alpha_{2} M M C_{i, t-1}+\text { Control }_{i, t(-1)}+\varepsilon_{i, t},
$$

where $Y$ is a vector of dependent outreach variables for bank $i$. As mentioned in the introduction, we make a distinction between bank access and use in our outreach measures. Access refers to the availability and affordability of financial services, whereas use refers to the actual consumption of financial services. In this study, access is defined as the availability of financial services in close proximity to the users. ${ }^{13}$ At the bank level, we use two proxies for access: investment in branch outlets (measured as the growth rate in the number of branches) and penetration to new markets (in terms of serving new provinces). For the actual use of financial services, we rely on the log of (1) the total volume of deposits at time $t,(2)$ the total number of deposit accounts at time $t$, and (3) the total volume of credits at time $t$. For the bank-level regressions only, our data allow us to distinguish between the number of deposit accounts and the volume of deposits. Furthermore, we can distinguish among several deposit accounts for the entire sample period: business deposit accounts, savings deposit accounts, and interbank deposit accounts. This enables us to verify whether competition has differential impacts on different types of deposit accounts. ${ }^{14}$

The primary explanatory variables are measures for competition and multimarket contact. To quantify the former, we use a structural measure of competition: the HerfindahlHirschman Index (HHI) of banking market concentration. ${ }^{15}$ We define the HHI as the sum of the squares of banks' market shares in the total number of branches. The index ranges between 0 and 1, where higher values represent higher levels of market concentration and, hence, lower levels of market competition. For the bank-level regressions, we introduce a proxy for the degree of competition faced by each bank in one specific year, which is the branch-weighted sum of the provincial HHI. More specifically, this bank-specific HHI is calculated as $H H I_{i, t}=\sum_{j} S_{i, j, t} * H H I_{j, t}$, where $S_{i, j, t}=B_{i, j, t} / \sum_{j=1}^{m} B_{i, j, t}, H H I_{j, t}$ is the HHI for the local market $j$ at time $t$, and $B_{i, j, t}$ is the number of branches of bank $i$ in the local market $j$ at time $t$. We interpret a positive (negative) association between market concentration and outreach as an indication that concentrated banking markets are more (less) favorable for outreach. ${ }^{16}$ 
However, traditional concentration measures such as HHI can be biased when firms meet one another in multiple local markets. The theory of multimarket contact suggests that mutual forbearance will show up when the correlation between two firms is high in terms of geographical coverage. ${ }^{17}$ The theory of multimarket contact is suitable for the banking industry as banks usually meet one another in several geographical markets via subsidiaries or branches. At the bank level, we measure multimarket contact (MMC) by considering the number of geographical contacts between banks (Coccorese and Pellecchia 2009; De Bonis and Ferrando 2000). Let $D_{i j}$ be equal to 1 if bank $i$ operates in province $j$, and 0 otherwise, for $i=1, \ldots, n$, and $j=1, \ldots, m$. We construct a symmetric $(n \times n)$ matrix $\mathrm{A}=\left(a_{i k}\right)$, where its generic element $a_{i k}=\sum_{j=1}^{m} D_{i j} D_{k j}$ represents the number of markets in which bank $i$ meets bank $k$, while the diagonal element $a_{i i}$ measures the number of markets serviced by bank $i$. In some markets, the interactions between banks is heavier, so we introduce a quadratic weighting structure by using the market shares in the calculation of multimarket contact. Therefore, we first produce an $(n \times m)$ matrix, with its generic element representing the share of the number of branches of bank $i$ in market $j$, calculated as $S_{i j}=B_{i j} / \sum_{i=1}^{n} B_{i j}$. We proceed with the calculation of a symmetric $(n \times n)$ matrix $R=\left(r_{i k}\right)$, where $r_{i k}=\sum_{j=1}^{m} S_{i j} S_{k j}$ is a weighted measure that captures the relative importance of bank $i$ and bank $k$ in the respective markets. In one specific year $t$, our indicator of multimarket contact $(M M C)$ for bank $i$ is calculated as $M M C_{i}=\Sigma_{k \neq i} r_{i k} \delta_{i k} /$ $\Sigma_{k \neq l} \delta_{i k}$, where $\delta_{i k}=1$ if $a_{i k}>0$ and 0 if $a_{i k}=0$. We repeat this calculation for every period $t$ to arrive at $M M C_{i, t}$.

The Control vector includes ownership structure, number of branches, profitability, and bank age. The variable State refers to banks that are primarily owned by the government. One of the strongest arguments in favor of state ownership in banking has been its ability to correct market failures. Specifically, state banks can pursue social policies rather than just profit maximization, and therefore, they can penetrate remote, unserved areas. ${ }^{18}$ The Foreign variable encompasses banks that either are branches of foreign banks or have at least 50 percent of their shares owned by nonresidents. Studies have generally shown that foreign bank entry is beneficial to the banking efficiency in emerging economies. This increased efficiency is attributed to foreign banks' superior expertise in the channeling of funds from depositors to creditors, their access to a greater variety of sources, and their reduced sensitivity to shocks in the host country (Berger et al. 2000; Bonin et al. 2005; Detragiache and Gupta 2006). However, despite the positive effects on bank efficiency, foreign banks are often criticized for cherry-picking the most creditworthy borrowers and depositors (Berger et al. 2005; Mian 2006). The limited empirical evidence generally suggests that foreign banks scale down bank outreach (Beck and Martinez Peria 2010; Detragiache et al. 2008). ${ }^{19}$ Private domestic banks serve as the reference group. To control for the existing business orientation of the bank and its size, we include the natural logarithm of the number of branches (i.e., the Branches variable). Furthermore, we verify whether profitability (in terms of return on assets, i.e., the variable $R O A$ ) and bank age (in terms of the natural logarithm of the number of years the bank is operating, i.e., the variable Age) are influencing outreach. We reduce concerns about potential endogeneity (i.e., reverse causality) problems through lagging all explanatory variables but ownership dummies by one period (i.e., variables are predetermined) and by exploiting the panel dimension of our data set. Bank dummy variables $\alpha_{i}$ are included to control for unobserved time-invariant bank-specific effects. Year dummy variables $\alpha_{t}$ control for macroeconomic fluctuations and other year-specific effects that may influence outreach. 
To assess the outreach impacts of competition on provincial markets, we estimate the following province-level equation:

$$
Y_{j, t}=\alpha_{j}+\alpha_{t}+\alpha_{1} H H I_{j, t-1}+\alpha_{2} M M C_{j, t-1}+\text { Control }_{j, t(-1)}+\varepsilon_{j, t},
$$

As proxies for outreach at the regional level, we use the following indicators: net branch entry (i.e., change in the total number of branches in a particular province $j$ ), per capita volume of credits, and per capita volume of deposits. We also differentiate among different deposit products. With these measures, we verify how the market equilibrium and competitive conditions in that market affect entry/outreach decisions.

For the measurement of competition and multimarket contact at the local level, we follow Degryse and Ongena (2007). Local market competition is calculated using the HHI of existing bank branches. Specifically, for a local market $j$ in year $t$ we define the HHI as: $H H I j=\sum_{i=1}^{n}\left(B_{i j} / \sum_{i=1}^{n} B_{i j}\right)^{2}$, where $n$ is the number of banks that operate in market $j$, and $B_{i j}$ is, as before, the number of branches of bank $i$ in market $j$. The disaggregation at the province level enables us to take advantage of the heterogeneous nature of the banking structure within a single institutional framework..$^{20}$ The regional multimarket contact variable is measured as the sum of all bank pairs in a particular region weighted by the bilateral contacts in other regions. As a starting point, we define an $(n \times m)$ matrix $C=\left(c_{i j}\right)$, with $i$ representing banks $(i=1, \ldots, n)$ and $j$ representing the provinces $(j=1, \ldots, m)$, where its generic element $c_{i j}$ represents the number of branches of bank $i$ in province $j$. Let $D_{i j}$ be equal to 1 if bank $i$ operates in province $j$ (i.e., if $c_{i j}>0$ ), and 0 otherwise, for $i=1, \ldots, n$, and $j=1, \ldots, m$. Let $f_{j}$ be equal to the number of different banks operating in region $j$, and let $a_{i k}=\sum_{j=1}^{m} D_{i j} D_{k j}$ represent the number of markets in which bank $i$ meets bank $k$, while the diagonal element $a_{i i}$ measures the number of markets serviced by bank $i$. In some markets, the interactions between banks is heavier, so we introduce a quadratic weighting structure by using the market shares in the calculation of multimarket contact. Therefore, we first produce an $(n \times m)$ matrix, with its generic element equal to the share of the number of branches of bank $i$ in market $j$, calculated as $S_{i j}=B_{i j} / \sum_{i=1}^{n} B_{i j}$. We proceed with the calculation of a symmetric $(n \times n)$ matrix $R=\left(r_{i k}\right)$, where $r_{i k}=\sum_{j=1}^{m} S_{i j} S_{k j}$ is a weighted measure that captures the relative importance of bank $i$ and bank $k$ in the respective markets. The multimarket contact in region $j$ (i.e., $M M C_{j}$ ) is calculated (as proposed by Evans and Kessides 1994) as

$$
\frac{2}{f_{j}\left(f_{j}-1\right)} \sum_{i=1}^{n} \sum_{k=i+1}^{n} r_{i k} D_{i j} D_{k j} .
$$

The variable is bounded between 0 (banks in the province have no contact elsewhere) and 1 (all banks in the province have contact with all other banks across all provinces). We repeat this calculation for every period $t$ to arrive at $M M C_{j, t}$.

The Control vector includes the bank ownership structure and the (natural logarithm of the) total number of bank branches in the provinces. The State variable is calculated as the proportion of the number of government-owned bank branches to the total number of branches in province $j$, and the variable Foreign is the ratio of the number of foreign bank branches to the total number of branches in province $j .{ }^{21}$ The Branches variable controls for both the relative size of the banking market and branch density in a particular province. Province dummy variables $\alpha_{j}$ are added to control for heterogeneous cultural environments, uneven economic development, and differences in living standards among provinces. All the correlates, except the ownership dummy variables, are lagged by one period. 
At the bank-province level, we estimate the following regression equation:

$$
\begin{aligned}
Y_{i, j, t}=\alpha_{i}+ & \alpha_{j}+\alpha_{t}+\alpha_{1} H H I_{i, t-1}+\alpha_{2} H H I_{j, t-1}+\alpha_{3} M M C_{i, t-1} \\
& +\alpha_{4} M M C_{j, t-1}+\text { Control }_{i, j, t(-1)}+\varepsilon_{i, j, t},
\end{aligned}
$$

where the indicators $i, j$, and $t$ represent bank, province, and time, respectively.

For each province $j$, in a particular year $t$, we have information about the number of branches a bank $i$ has, and we know the type of bank $i$ (i.e., state-owned, privately owned, foreign-owned, and investment banks)..$^{22}$ At the level of provinces, we have access to information on the volume of credits granted and the volume of deposits (total and subcategories) generated by bank type. These figures enable us to calculate an accurate estimate of the volumes of credits and deposits (and different categories of deposits) that bank $i$ produces in province $j$. As proxies for outreach at the bank-province level, we use the following indicators: branch expansion (i.e., a dummy variable equal to 1 if the number of branches is higher than the previous year and otherwise 0 ), per capita volume of credits, and per capita volume of deposits. We differentiate between different deposit products. We include simultaneously both of the HHI and MMC parameters used in the previous two regressions levels as independent variables in order to verify whether the bank and province indicators have differential impacts on outreach. The Control vector includes the ownership structure and the number of branches the bank $i$ has in province $j .{ }^{23}$ Again, all the correlates, except the ownership dummy variables, are lagged by one period.

\section{Data Sources}

Our primary data are retrieved from various issues of Banks in Turkey published by the Banks Association of Turkey (www.tbb.org.tr/en/) for the period 1988-2010, an era of a liberalized financial system. These issues include annual information about the number of branches, the number/volume of deposit accounts, and the volume of credits for all conventional banks operating in Turkey. The number (and different types) of deposit accounts and total volumes of deposits/credits are available at the bank level. The volume of deposits (and different types of deposits) and credits per ownership type are available at the province level. Information about the number of branches is available on three levels: bank, province, and bank-province. Irrespective of this disaggregation, we also have information on the ownership type (state, private, and foreign) of all operating banks. Hence, combining the bank-branch information on the bank-province level with volume of deposits and credits at the province level, we can calculate a fair proxy for the volume of deposits and credits at the bank-province level. At the beginning of the sample period, there were sixty-seven provinces in Turkey. During the sample period, fourteen new provinces were established from existing provinces. In order to tackle the artificial decline in the levels of deposits and credits in the existing provinces, we classify the split provinces as newly formed and assign them unique province identifiers. ${ }^{24}$ All the volume variables are expressed in constant prices. Definitions and descriptive statistics of all the variables are exhibited in Table 1.

\section{Estimation Results}

We start with regression results at the bank level. Next, we turn to province-level regressions. Finally, we report the results using the bank-province panel estimations. In all levels, we use annual data for the period 1988-2010. 


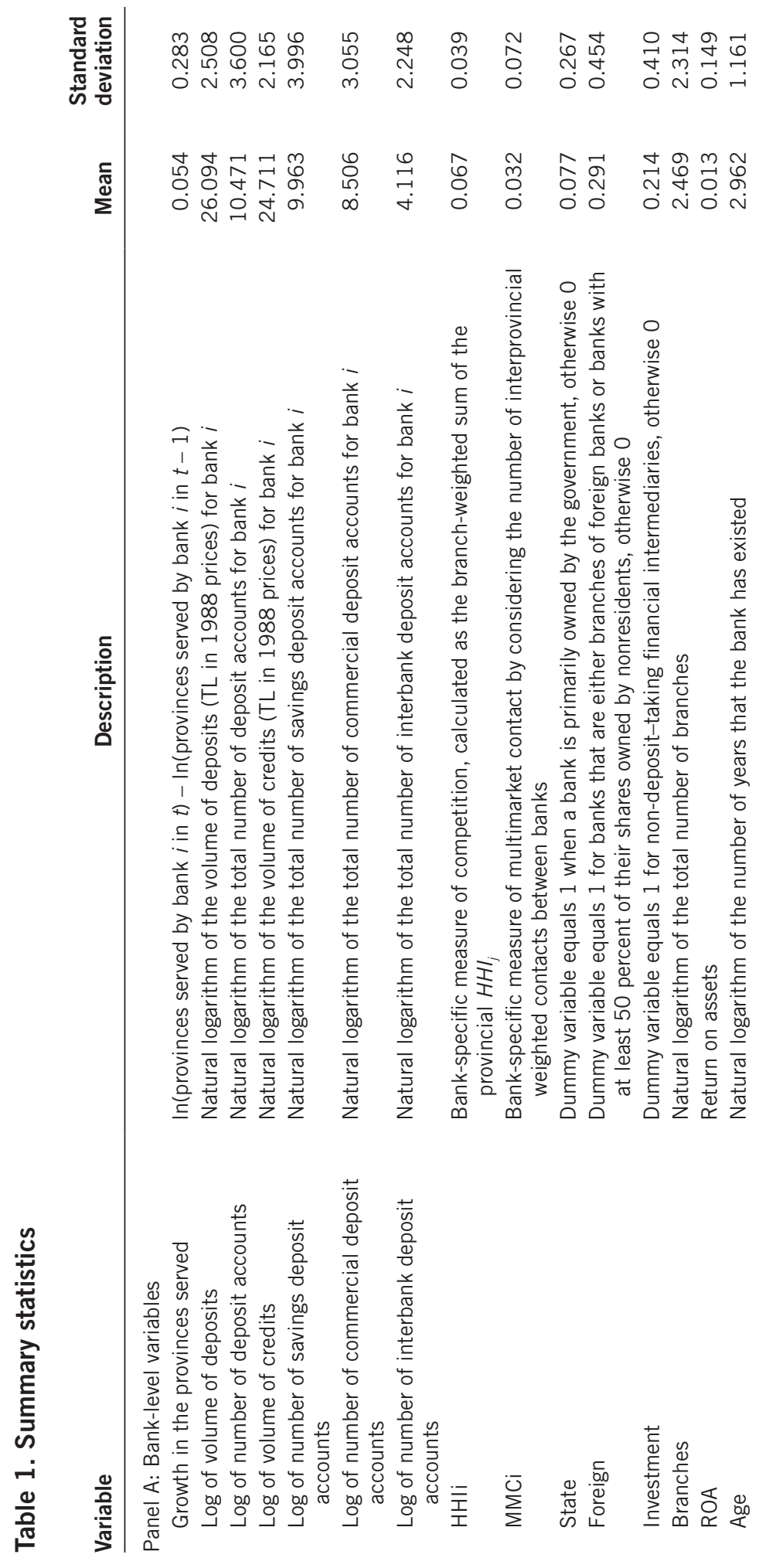




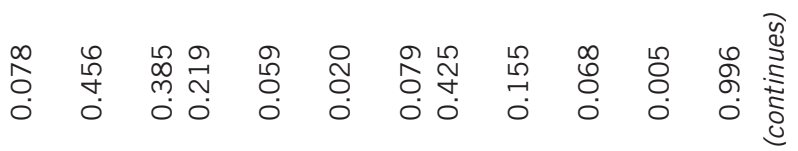

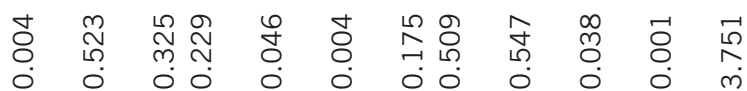

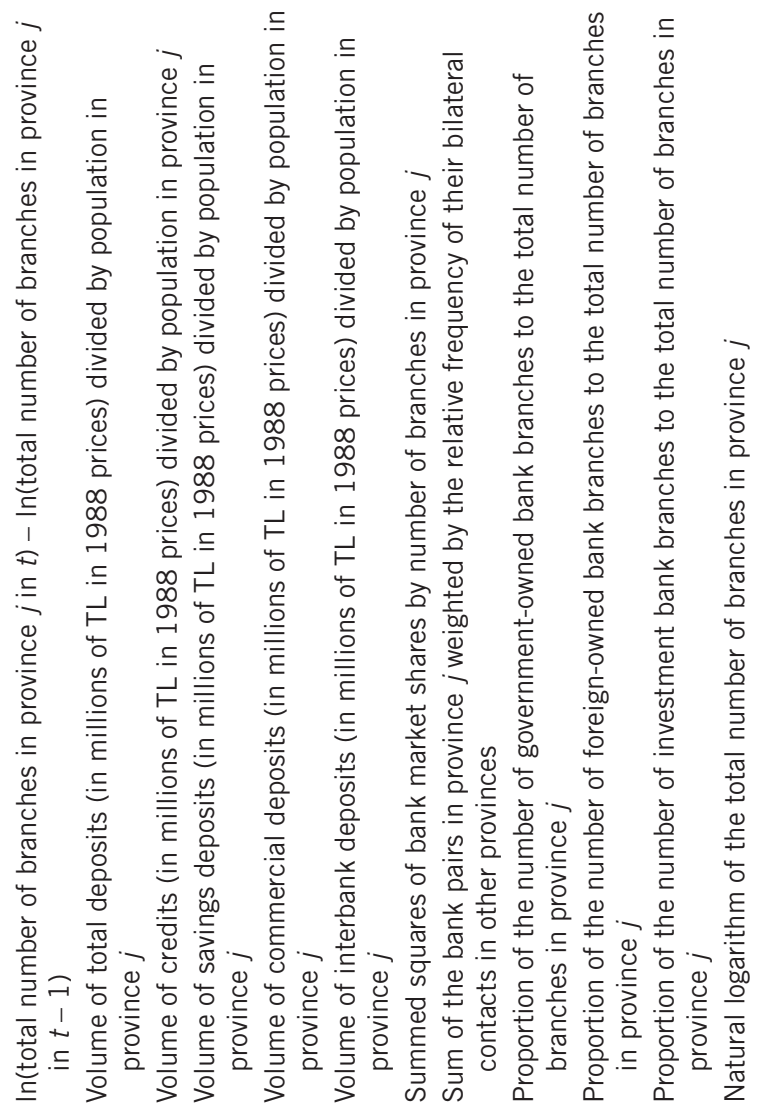

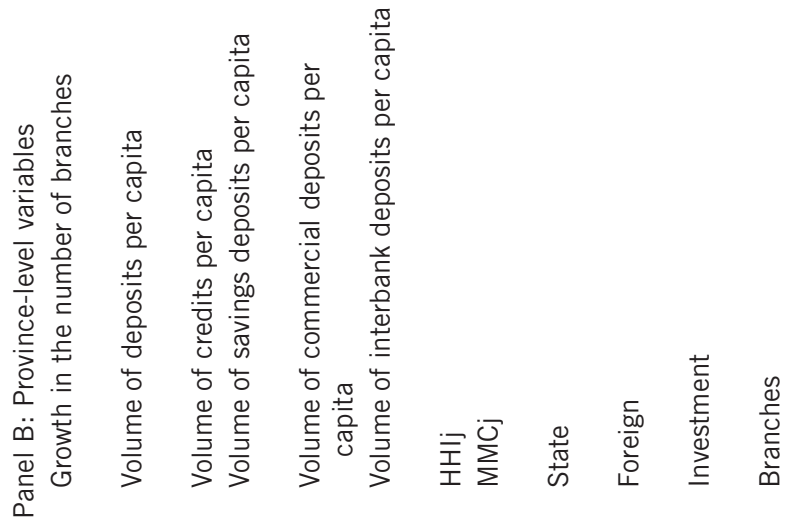




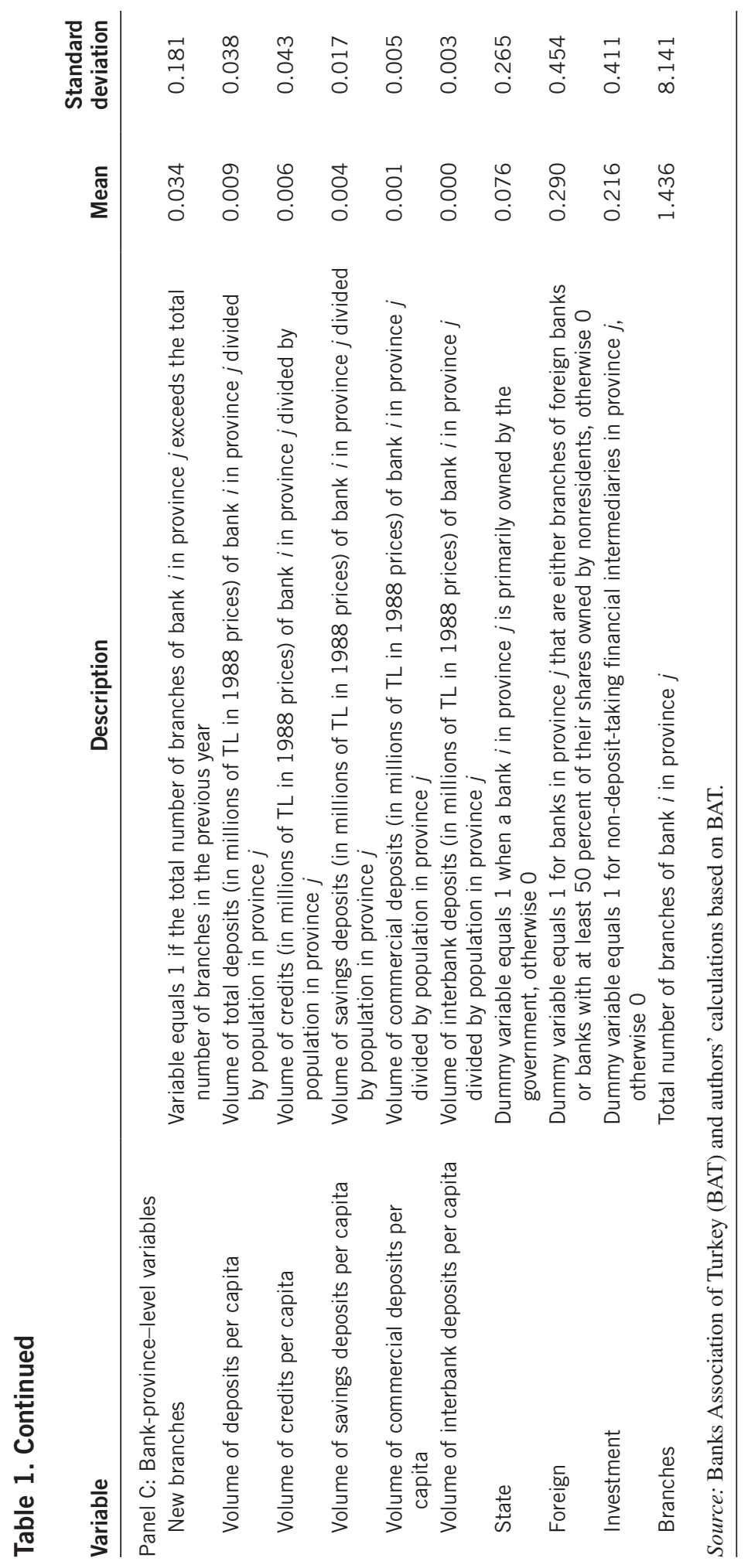




\section{Evidence from Bank-Level Regressions}

We start by testing for the presence of unit roots using the augmented Dickey-Fuller (ADF) panel unit root test of Maddala and Wu (1999), which does not require a balanced panel as do most tests. Maddala and Wu suggest combining the $p$-values of the test-statistic for a unit root in each bank. The results reject the null of nonstationarity for all variables at the 5 percent level. ${ }^{25}$ We let the Hausman test determine the choice between fixed and random effects. The robust Hausman test for all specifications of model (1) indicates the difference between fixed effects (FE) and random effects (RE) is systemic, providing evidence in favor of the FE model. ${ }^{26}$

In Table 2, we report the estimates of the determinants of model 1. An analysis of Panel A of this table reveals that competition is driving banks to seek new markets. Higher levels of competition (lower HHI) lead to an increase in the penetration of new provinces (i.e., forming branches in unexplored provinces). This result indicates that competition is fostering broader physical outreach. Next to the positive effect of competition on exploring new markets, we find that profitable and younger banks are more likely to penetrate into new provinces. In addition, we find that a higher level of competition encourages banks to extend more credit and attract higher volumes of deposits and increased numbers of deposit accounts. Competition makes the financial system more inclusive. These findings are in line with the conventional competition interpretation that a high concentration of market power in banking gives a lower equilibrium amount of deposits and credits. The multimarket hypothesis states that more contacts between firms in the same markets may lead to more collusion. In our empirical framework, the collusive behavior triggered by multimarket competition among banks will be expressed as an increase in bank margins (lower cost of funding will lead to lower deposit quantities, and a higher charge on loans will lead to a decrease in credit quantities). We do not find support for this hypothesis. Our results indicate that multiple contacts among banks lead to higher volumes and numbers of deposits and do not have any effect on the credit market. We interpret this finding as evidence that collusive behavior among banks is less likely when barriers to entry and exit are absent. This finding is also consistent with De Bonis and Ferrando (2000) for the Italian banking market, reporting an increase in the loan market share (because of lower lending rates) for banks with greater multimarket linkages.

We also find that state- and foreign-owned banks extend higher volumes of credit than do their private counterparts. However, everything else being equal, state-owned banks are not successful in attracting deposits compared to their private peers. In line with Evanoff (1988), we find that banks with higher numbers of branches have an advantage in the acquisition and servicing of both deposits and credits. ${ }^{27}$ Table 2, Panel B shows that our previous results for the deposit market are driven primarily by the savings deposits. There is no impact of competition in attracting interbank deposit accounts, as was to be expected. State-owned banks and profitable, older banks are successful in attracting bank deposits. In sum, we observe that more competition, higher multimarket links, and economies of scale enable banks to have pro-outreach activities in terms of both attracting deposits and servicing credits.

\section{Evidence from Province-Level Regressions}

While the bank-level regressions allow us to explore the impact of competition among banks at the country level, the province-level regressions allow us to exploit the regional 


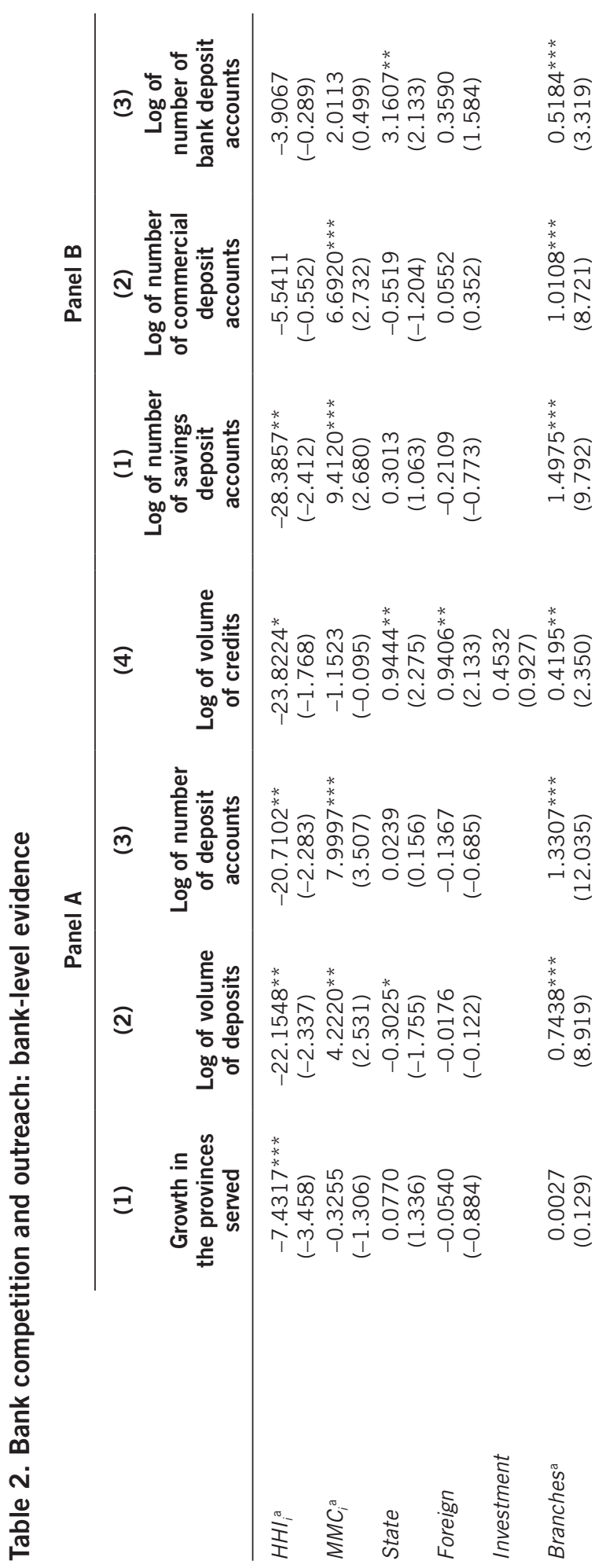




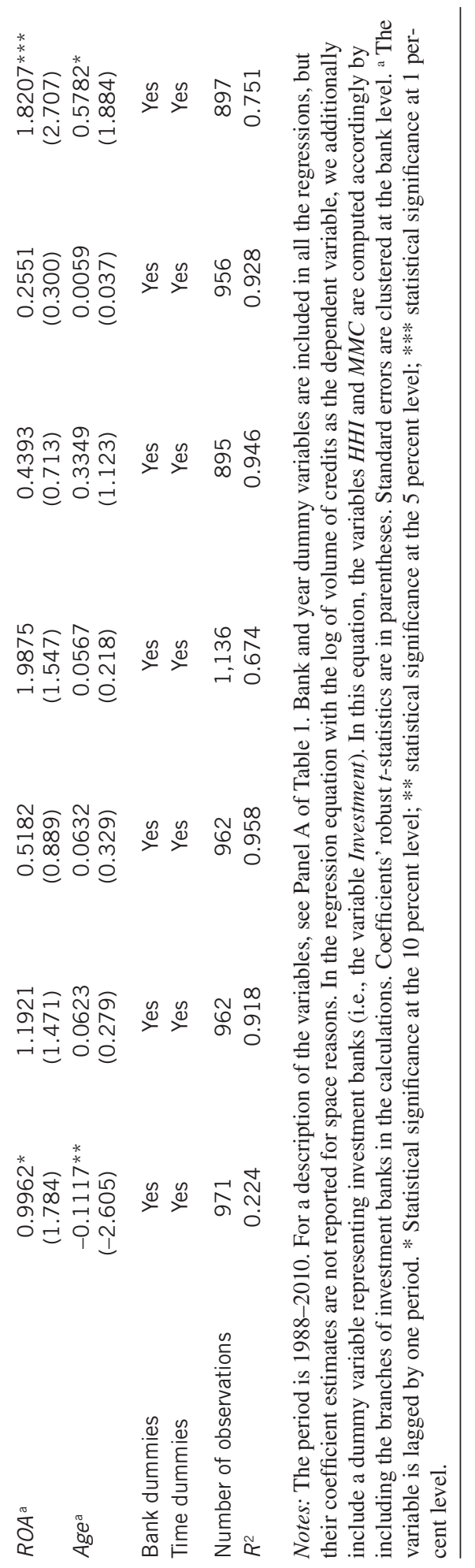


nature of banking market competition. ${ }^{28}$ Conventional theory asserts that the less competitive conditions in the regional market will produce lower outreach by financial institutions. In Table 3, which shows the regression results for model 2, we test this hypothesis at the province level by introducing province-specific outreach and competition measures. The results confirm our previous findings. Although we find that provinces with competitive banking markets have a lower growth in the number of branches compared to concentrated banking market provinces, we also find that competition is conducive to attracting more deposits (mainly driven by the volume of savings deposits) and granting more loans. We again confirm the earlier result that higher multimarket competition is not associated with collusive behavior. Indeed, in markets where the competing banks have extensive multimarket contacts, banks tend to attract more deposits and issue more loans. This finding is consistent with Rosen's (2007) analysis, showing that markets with multimarket banks have higher deposit rates (i.e., they attract more deposits). ${ }^{29}$ At a disaggregated level, we find that provinces with a high presence of foreign banks (measured as the ratio of the number of foreign bank branches to the total number of branches) offer financial services to a broader base of clients in terms a higher growth of the number of bank branches and higher deposit and credit volumes. This result is consistent with those of some studies in favor of foreign bank entry (see, e.g., Giannetti and Ongena 2005; Jeon et al. 2011).

\section{Evidence from Bank-Province-Level Regressions}

While the results using bank-panel regressions allow us to identify the impact of competition on outreach for each bank over all provinces and the province-level regressions show the association between regional outreach and competition, the bank-province-level regressions in Table 4 (compare the regression results of model 3) enable us to identify the ability of banks to reach out to a broader customer base in response to the local competitive environment in which they are located. In doing so, to have a more complete assessment, we control not only for the competitive environment in each province $\left(H H I_{j}\right)$ but also for the competition that each bank faces over all provinces $\left(H H I_{i}\right)$. We find that banks facing competition $\left(H H I_{i}\right)$ do open new branches but not in provinces with relatively more competitive banking markets $\left(H H I_{j}\right)$. Banks that have high levels of multimarket contact among banks $\left(M M C_{i}\right)$ and are present in provinces where banks have extensive interprovincial contacts $\left(M M C_{j}\right)$ are likely to open fewer new branches but attract more deposits and issue more loans, confirming at the bank-province level our earlier evidence that multimarket contact is not associated with collusive behavior. The volume of both deposits per capita and credits per capita is increasing with competition that banks face $\left(H H I_{i}\right)$ and in provinces with a higher level of competition $\left(H H I_{j}\right)$, again confirming that competition boosts bank outreach. Furthermore, the increase of the total volume of deposits is mainly driven by the volume of savings deposits and less so by the volume of commercial deposits (see panel B of Table 4).

Ownership types at the bank-province level provide us additional insights. At the province level, and to a lesser extent at the bank level, we find that foreign bank presence is conducive to outreach. At the bank-province level, however, we find that foreign banks offer fewer per capita deposits and less credit then domestic banks, clearly indicating that foreign banks do not boost outreach by offering higher levels of deposits and issuing more loans, but by increasing competitive pressure and inducing domestic banks to offer higher levels of deposits and issue more loans. Jeon et al. (2011), who find that an 


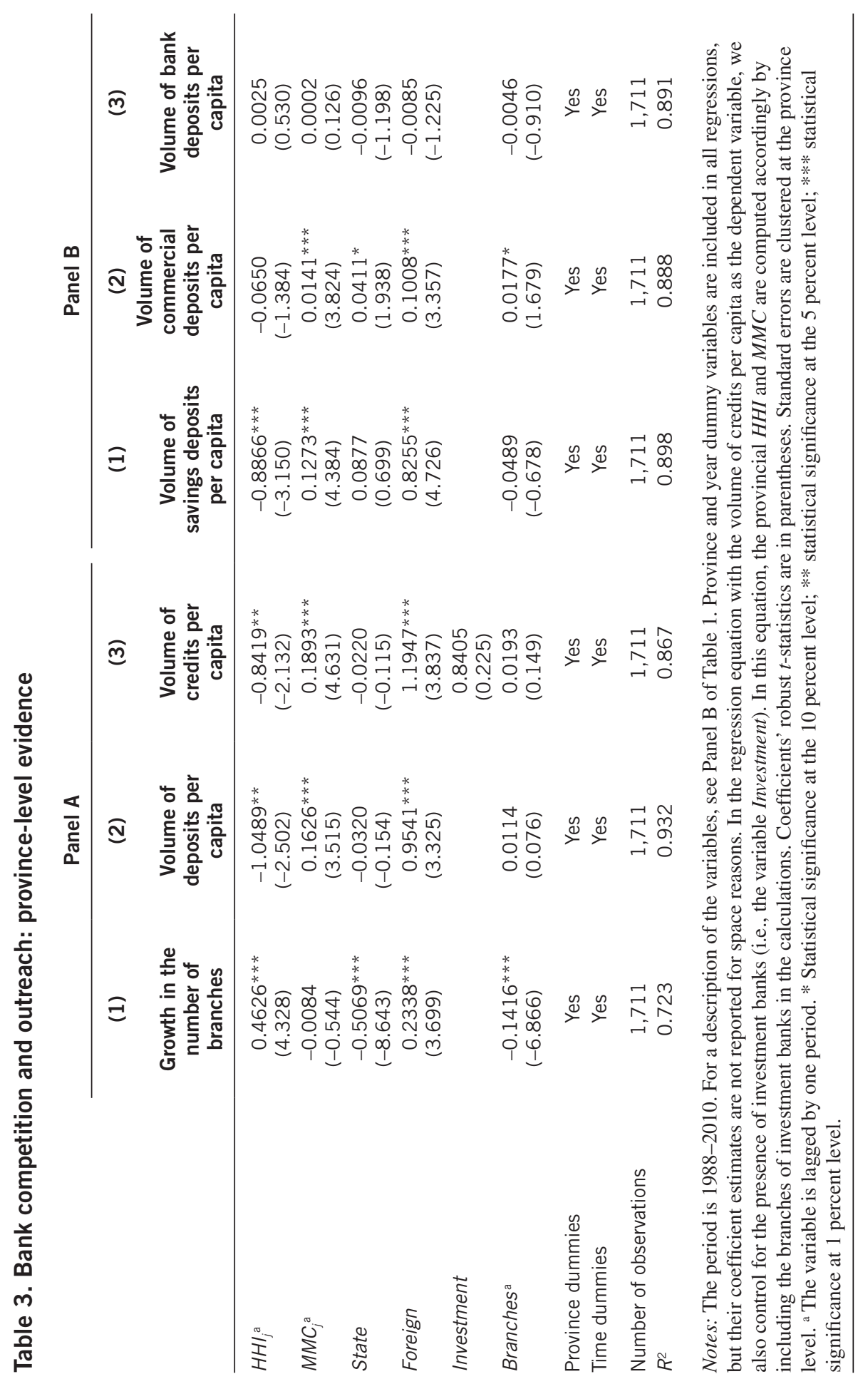




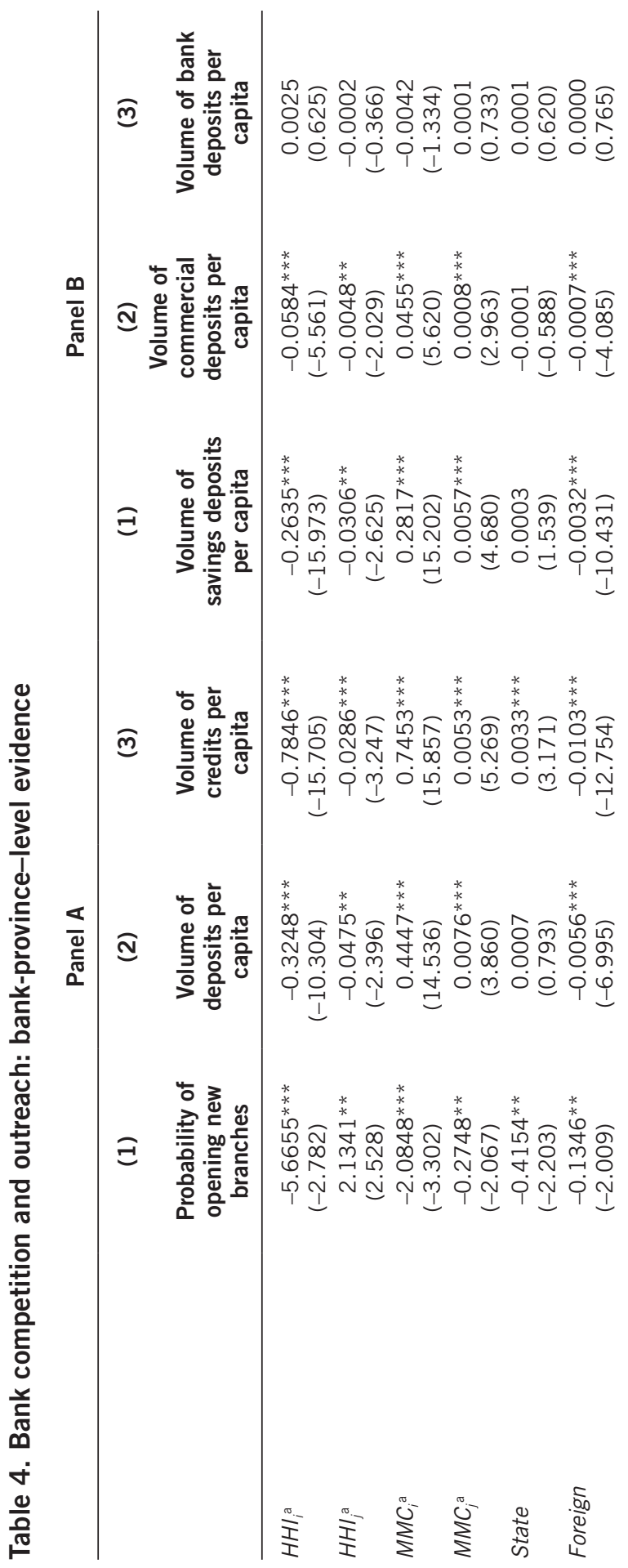




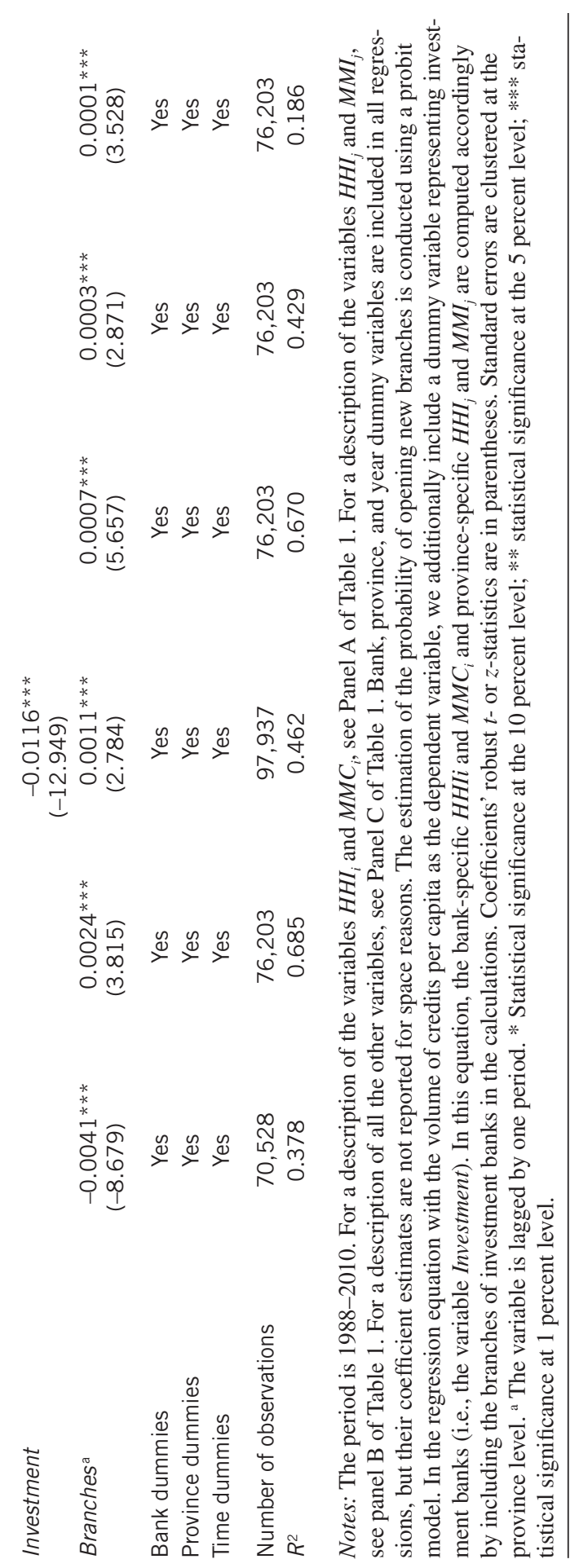


increase in foreign bank penetration enhances competition in the host countries' banking sectors, offer a similar finding.

\section{Concluding Remarks}

Although the benefits of increased access to finance are intuitively well understood, this understanding is still absent as regards the influence of competition on banking sector outreach. The effect of competition on outreach may go both ways and deserves an empirical investigation. Contrary to the conventional view that a competitive banking market leads to an increase in both the equilibrium amounts of credit (thanks to lower borrowing costs) and deposits (thanks to higher savings rates), it has also been claimed that market power is needed to establish relationship banking for an optimal use of financial services. In line with the traditional assumptions, we find on the level of banks that competition (i.e., decreasing margins) is driving banks to explore new markets, extend more credit, and attract more deposits. This finding is confirmed on the province-level and bank-provincelevel regressions. The results are in line with the market power hypothesis that suggests that less competitive banking markets lead to more credit rationing and less competitive deposit rates (i.e., eroding the consumer surplus). In addition, on the bank-province level, we find that banks facing competition do open new branches but in less competitive markets. Across specifications, we do not find that multimarket contact is causing collusive behavior among banks. On the contrary, we find that outreach is strengthened through multimarket contact linkages, portraying the existence of a contestable market. Finally, our results indicate that the presence of foreign banks is associated with higher outreach, while at the bank-province level we observe that outreach of domestic banks exceeds that of foreign banks. Together, these results suggest that there are procompetitive spillover effects from foreign banks to their domestic counterparts that boost banking outreach.

From a policy perspective, our results indicate that the government should promote banking competition in all parts of the country. Moreover, especially in regions with a strong banking concentration, regulatory authorities will need to make a decision on how to stimulate regional competition (e.g., through encouraging bank entry) to further the goals of financial inclusion. As competition may have adverse interactions with financial stability, appropriate safeguards should be provided to ensure compliance and bank safety. Through regional diversification, banks can also mitigate adverse region-specific shocks and therefore can achieve superior risk/return trade-offs (e.g., Acharya et al. 2006). Although individual foreign banks exhibit relatively modest levels of regional outreach, their presence stimulates regional competition and fosters outreach of domestic banks in the same region. However, more research will be needed to confirm and widen these findings and to identify the channels through which foreign bank entry (e.g., de novo entry or acquisition of existing banks) is conducive for competition.

\section{Notes}

1. Berger et al. (2001) and Elsas (2005) empirically support the argument that competition may actually strengthen relationship banking.

2. Another question that is not yet resolved is whether bank competition is good or bad for financial stability. The "competition-fragility" hypothesis suggests that a competitive banking market will increase financial fragility. Higher banking profits and the existence of monopoly rents, associated with market power, will armor the bank against negative shocks, thereby increasing the franchise value of the bank. Furthermore, bank managers will not have adverse incentives to 
take excessive risk in a concentrated market (see, e.g., Allen and Gale 2004; Besanko and Thakor 1993). An opposing view, the "competition-stability" hypothesis proposes that concentration will increase the intermediation margin. An increase in the interest rate charged to firms will amplify adverse selection and moral hazard considerations, which will lead to a deterioration of credit quality and an increase in banking system vulnerability (e.g., Boyd and De Nicoló 2005; Caminal and Matutes 2002).

3. Using data on U.S. banking markets, Cetorelli and Strahan (2006) find that increased competition among banks in local markets is associated with the creation of new establishments due to enhanced access to finance. Corvoisier and Gropp (2002) find a positive relationship between concentration and price-cost margins for European banks, which is detrimental for business creation.

4. Other studies in favor of or against more competition include the following: Cetorelli (2003) shows that competition is positively associated with firm entry; Zarutskie (2006) finds that concentrated banking markets smooth loan rates and hence provide more financing to borrowers; Maurer and Haber (2007), using nineteenth-century data from Mexico, provide evidence that bank concentration is in favor of related lending to connected borrowers; and Saeed and Vincent (2012) show that bank concentration elevates financial constraints for a sample of Indian firms.

5. The discussion, in fact, relates also to the general finance-growth literature, and more specifically to the literature concerning the welfare impacts of inclusive financial systems. A vast body of research emphasizes the benefits of well-developed and inclusive financial systems for poverty alleviation and economic development (e.g., Cetorelli and Gambera 2001; Demirgüç-Kunt and Maksimovic 1998; King and Levine 1993; Levine 1997; Rajan and Zingales 1998). Financial institutions contribute to economic growth by mitigating frictions between lenders and borrowers and thus improve the efficiency of capital and resource allocation decisions.

6. Having access to bank accounts is considered the entry point for individuals to enhance their participation in the formal economy and society. The use of deposit accounts is valued both for facilitating transactions and for smoothing consumption. Furthermore, deposit accounts make account holders better positioned for loan approvals as savings can serve not only as collateral, but also as evidence of financial discipline (Udell 2004). According to Mester et al. (2007), transaction accounts foster relationship banking as it provides banks privileged information about firms' different revenue sources over time.

7. Focus on the most profitable customers and regions, known as cherry picking, will lead to less outreach because of increased segmentation.

8. Maintaining proximity to customers is considered a very favorable characteristic for providing relationship banking. Moreover, proximity banks are found to be better positioned in extracting location rents from their clients (Degryse and Ongena 2005).

9. While some papers point to procompetitive effects of multimarket contact (e.g., Mester 1987, 1992), the prevailing thought is that multimarket contacts allow competitive responses across markets, discouraging banks to compete aggressively as they fear rivals' retaliation in other markets.

10. State-owned banks make financial services available to many geographically remote regions and to poor people. Their privatization as a policy recommendation, therefore, presents a political dilemma as commercial missions may outweigh social objectives, and this may lead to less banking in rural or nonprofitable regions.

11. There is also the argument that foreign banks decrease financing obstacles (Clarke et al. 2001) and introduce superior risk management techniques enabling them to reach a broader customer base (Berger and Udell 2006).

12. We follow an empirical strategy similar to Beck and Martinez Peria (2010), who show that, between 1997 and 2005, the increasing presence of foreign banks in Mexico was detrimental for bank outreach.

13. Other aspects of access such as data on cost and quality of services are much harder to obtain and are therefore not part of the analysis.

14. Subcategory information for the volume of deposits is unfortunately not available for the bank-level estimations but is available for the other two levels (province and bank-province) of regressions. Because the number of deposit accounts is regionally not available for the other two levels of regressions, we proceed with the volume of deposits. Information about the number of loan contracts is also not available.

15. We prefer to use HHI since it is the most widely used measure of banking structure and indicator for competition in both theoretical (e.g., Boot and Thakor 2000; Petersen and Rajan 
1995) and empirical analyses (e.g., Black and Strahan 2002; Cetorelli and Strahan 2006; Degryse and Ongena 2007).

16. Banking concentration studies in the United States often use the deposit market shares in the calculation of HHI. However, we follow Degryse and Ongena (2007) and Elsas (2005) and use branch market shares as the branch serves as a more neutral benchmark for both the assets side (i.e., credits) as well as the liabilities side (i.e., deposits). In addition, it is shown by Fisher (2001) that branch HHI and deposits HHI are highly correlated for U.S. metropolitan statistical areas.

17. For example, a bank branch that pursues an aggressive growth strategy in a particular region may trigger retaliatory actions by rivals not only in that region but also in other regions. Consequently, fears of multimarket retaliation temper aggressive behavior and may result in reduced competitive intensity.

18. In this vein, authorities face a serious political dilemma because privatization can be at the detriment of bank access when privatized banks decide to close outlets in small and remote regions. Furthermore, Denis et al. (2002) and Kim and Mathur (2008) show that geographic diversifications are associated with firm value decrease, suggesting that corporate diversification costs (due to more complex coordination problems) are outweighing the benefits of diversification (through economies of scale and scope). In such a situation, privatized banks can choose to operate in fewer markets. Apart from this social view, it has also been suggested that state-owned banks are, rather, used as instruments for maximizing politicians' personal objectives (Dinç 2005; La Porta et al. 2002; Sapienza 2004).

19. In the regression equation with the log of volume of credits as a dependent variable, we additionally include a dummy variable representing investment banks. The Investment variable equals 1 for non-deposit-taking financial intermediaries and 0 otherwise. The assumption is that commercial banks could also compete with investment banks in providing finance for borrowers. In this equation, the $H H I$ and $M M C$ are computed accordingly by including the branches of investment banks in the calculations.

20. Moreover, the measurement of banking structure at the disaggregated level provides the advantage of taking into account the locality of relevant geographical markets for banking services, especially for opaque firms and retail customers (e.g., Berger et al. 1999; Cetorelli and Strahan 2006).

21. In the regression equation with the volume of credits per capita as a dependent variable, we also control for the presence of investment banks. The Investment variable is the proportion of the number of investment bank branches to the total number of branches in a particular province. The assumption is that commercial banks could also compete with investment banks in providing financing for borrowers in a particular province. In this equation, the provincial $H H I$ and $M M C$ are also computed accordingly by including the branches of investment banks in the calculations.

22. Only in the regression equation with the volume of credits per capita as the dependent variable, we additionally control for investment banks by including a dummy variable that equals 1 if a non-deposit-taking financial intermediary exists in province $j$, and 0 otherwise.

23. At the bank-province level, the number of branches is used directly instead of the natural logarithm of branches in order to avoid losing observations.

24. We refer to Alper and Önis (2003), Kilinç et al. (2012), Laeven and Valencia (2012), and Tanyeri (2010) for an excellent discussion about the historical developments in the Turkish economy and, in particular, its financial sector. We refer also to a series of papers written by Önder and Özyildirim $(2010,2011)$ and Özyildirim and Önder (2008) for an overview of the intermediating role of banks in Turkish regions.

25. For the sake of brevity, the test results are not shown, but they will be made available upon request. Note, however, that individual intercepts are included as exogenous variables in the test equations. Except for the variable "Growth in the provinces served," the reported statistics and conclusions are obtained using one-lagged first-difference terms.

26. This test is similar to the classical Hausman test but has the advantage that is also applicable in the event of clustered errors, which are used to correct for within-bank serial correlation (Schaffer and Stillman 2011). Furthermore, the estimation results show that bank- and time-effects are present, since the relevant $F$-statistics for all specifications are significant at the 5 percent level.

27. Larger Turkish banks not only issue more loans or attract more deposits, they also manage their assets and liabilities in a more risk/return efficient manner (De Jonghe et al. 2012).

28. As a pretest, we first check the stationarity of model (2) using the ADF panel unit root test of Maddala and $\mathrm{Wu}(1999)$. Although we do not show the test results here owing to lack of 
space, the results reject the null hypothesis of nonstationarity for all the variables. Note, however, that individual intercepts are included as exogenous variables in test equations. Except for the variable "Growth in the number of branches," the reported statistics and conclusions are obtained using one-lagged first-difference terms. A robust Hausman test for all specifications of model (2) indicates a systemic difference between FE and RE, providing evidence in favor of the FE model. Since the relevant F-statistics for all specifications are significant at the 5 percent level, we can conclude that province- and time-fixed effects are present. The results are available upon request from the authors.

29. Park and Pennacchi (2009) find that the presence of multimarket banks in local markets results in both lower loan rates (i.e., procompetitive effect) and lower deposit rates (i.e., contracompetitive) due to their funding advantages in wholesale markets. However, according to Rosen (2007), multimarket becomes positively related with interest rates (procompetitive) with the inclusion of fixed effects in the estimations.

\section{References}

Acharya, V.; I. Hasan; and A. Saunders. 2006. "Should Banks Be Diversified? Evidence from Individual Bank Loan Portfolios." Journal of Business 79, no. 3: 1355-1412.

Allen, F., and D. Gale. 2004. "Competition and Financial Stability." Journal of Money, Credit and Banking 36, no. 3 (Part 2): 453-480.

Alper, C.E., and Z. Önis. 2003. "Financial Globalization, the Democratic Deficit, and Recurrent Crises in Emerging Markets: The Turkish Experience in the Aftermath of Capital Account Liberalization.” Emerging Markets Finance \& Trade 39, no. 3: 5-26.

Beck, T., and M.S. Martinez Peria. 2010. "Foreign Bank Participation and Outreach: Evidence from Mexico." Journal of Financial Intermediation 19, no. 1: 52-73.

Beck, T.; A. Demirgüç-Kunt; and R. Levine. 2007. "Finance, Inequality and the Poor." Journal of Economic Growth 12, no. 1: 27-49.

Beck, T.; A. Demirgüç-Kunt; and V. Maksimovic. 2004. "Bank Competition and Access to Finance: International Evidence." Journal of Money, Credit and Banking 36, no. 3 (Part 2): 627-648.

Berger, A.N., and G.F. Udell. 2006. "A More Complete Conceptual Framework for SME Finance.” Journal of Banking \& Finance 30, no. 11: 2945-2966.

Berger, A.N.; R.S. Demsetz; and P.E. Strahan. 1999. "The Consolidation of the Financial Services Industry: Causes, Consequences, and Implications for the Future." Journal of Banking \& Finance 23, no. 2-4: 135-194.

Berger, A.N.; L.G. Goldberg; and L.J. White. 2001. "The Effects of Dynamic Changes in Bank Competition on the Supply of Small Business Credit." European Finance Review 5, nos. 1-2: $115-139$.

Berger, A.N.; R.J. Rosen; and G.F. Udell. 2007. "Does Market Size Structure Affect Competition? The Case of Small Business Lending." Journal of Banking \& Finance 31, no. 1: 11-33.

Berger, A.N.; R. DeYoung; H. Genay; and G.F. Udell. 2000. "Globalization of Financial Institutions: Evidence from Cross-Border Banking Performance." Brookings-Wharton Papers on Financial Services 3: 23-120.

Berger, A.N.; N.H. Miller; M.A. Petersen; R.G. Rajan; and J.C. Stein. 2005. "Does Function Follow Organizational Form? Evidence from the Lending Practices of Large and Small Banks." Journal of Financial Economics 76, no. 2: 237-269.

Bernheim, B.D., and M.D. Whinston. 1990. "Multimarket Contact and Collusive Behavior." RAND Journal of Economics 21, no. 1: 1-26.

Besanko, D., and A.V. Thakor. 1993. "Relationship Banking, Deposit Insurance and Bank Portfolio Choice." In Capital Markets and Financial Intermediation, ed. C. Mayer and X. Vives, pp. 292-318. Cambridge: Cambridge University Press.

Black, S.E., and P.E. Strahan. 2002. "Entrepreneurship and Bank Credit Availability." Journal of Finance 57, no. 6: 2807-2833.

Bonaccorsi di Patti, E., and G. Dell'Ariccia. 2004. "Bank Competition and Firm Creation." Journal of Money, Credit and Banking 36, no. 2: 225-251.

Bonin, J.P.; I. Hasan; and P. Wachtel. 2005. "Privatization Matters: Bank Efficiency in Transition Countries." Journal of Banking \& Finance 29, nos. 8-9: 2155-2178. 
Boot, A.W.A., and A.V. Thakor. 2000. “Can Relationship Banking Survive Competition?” Journal of Finance 55, no. 2: 679-713.

Boyd, J.H., and G. De Nicoló. 2005. "The Theory of Bank Risk Taking and Competition Revisited." Journal of Finance 60, no. 3: 1329-1343.

Caminal, R., and C. Matutes. 2002. "Market Power and Banking Failures." International Journal of Industrial Organization 20, no. 9: 1341-1361.

Cetorelli, N. 2003. "Life-Cycle Dynamics in Industrial Sectors: The Role of Banking Market Structure.” Federal Reserve Bank of St. Louis Review 85, no. 4: 135-147.

Cetorelli, N., and M. Gambera. 2001. "Banking Market Structure, Financial Dependence and Growth: International Evidence from Industry Data.” Journal of Finance 56, no. 2: 617-648.

Cetorelli, N., and P.E. Strahan. 2006. "Finance as a Barrier to Entry: Bank Competition and Industry Structure in Local U.S. Markets.” Journal of Finance 61, no. 1: 437-461.

Clarke, G.R.G.; R. Cull; and M.S. Martinez Peria. 2001. "Does Foreign Bank Penetration Reduce Access to Credit in Developing Countries? Evidence from Asking Borrowers.” Policy Research Working Paper no. 2716, World Bank, Washington, DC.

Coccorese, P., and A. Pellecchia. 2009. "Multimarket Contact and Profitability in Banking: Evidence from Italy." Journal of Financial Services Research 35, no. 3: 245-271.

Corvoisier, S., and R. Gropp. 2002. "Bank Concentration and Retail Interest Rates." Journal of Banking \& Finance 26, no. 11: 2155-2189.

De Bonis, R., and A. Ferrando. 2000. "The Italian Banking Structure in the 1990s: Testing the Multimarket Contact Hypothesis.” Economic Notes 29, no. 2: 215-241.

Degryse, H., and S. Ongena. 2005. "Distance, Lending Relationships, and Competition.” Journal of Finance 60, no. 1: 231-266.

- 2007. "The Impact of Competition on Bank Orientation." Journal of Financial Intermediation 16, no. 3: 399-424.

De Jonghe, O.; M. Disli; and K. Schoors. 2012. "Corporate Governance, Opaque Bank Activities and Risk/Return Efficiency: Pre- and Post-Crisis Evidence from Turkey.” Journal of Financial Services Research 41, nos. 1-2: 51-80.

Deming, W.E. 1993. “The New Economics.” Massachusetts Institute of Technology, Center for Advanced Engineering Study, Cambridge, MA.

Demirgüç-Kunt, A., and V. Maksimovic. 1998. "Law, Finance, and Firm Growth.” Journal of Finance 53, no. 6: 2107-2131.

Denis, D.J.; D.K. Denis; and K. Yost. 2002. "Global Diversification, Industrial Diversification, and Firm Value.” Journal of Finance 57, no. 5: 1951-1980.

Detragiache, E., and P. Gupta. 2006. "Foreign Banks in Emerging Market Crises: Evidence from Malaysia.” Journal of Financial Stability 2, no. 3: 217-242.

Detragiache, E.; T. Tressel; and P. Gupta. 2008. "Foreign Banks in Poor Countries: Theory and Evidence." Journal of Finance 63, no. 5: 2123-2160.

DeYoung, R.; L.G. Goldberg; and L.J. White. 1999. "Youth, Adolescence, and Maturity of Banks: Credit Availability to Small Business in an Era of Banking Consolidation." Journal of Banking \& Finance 23, nos. 2-4: 463-492.

Dinç, I.S. 2005. "Politicians and Banks: Political Influences on Government-Owned Banks in Emerging Markets.” Journal of Financial Economics 77, no. 2: 453-459.

Elsas, R. 2005. "Empirical Determinants of Relationship Lending." Journal of Financial Intermediation 14, no. 1: 32-57.

Evanoff, D.D. 1988. "Branch Banking and Service Accessibility." Journal of Money, Credit and Banking 20, no. 2: 191-202.

Evans, W.N., and I.N. Kessides. 1994. "Living by the 'Golden Rule': Multimarket Contact in the U.S. Airline Industry.” Quarterly Journal of Economics 109, no. 2: 341-366.

Fischer, K.-H. 2001. "Banken und Unvollkommener Wettbewerb: Empirische Beiträge zu einer Industrieökonomik der Finanzmärkte" [Banks and Imperfect Competition: Empirical Contribution to the Industrial Economics of Financial Markets]. Working Paper, Goethe University, Frankfurt.

Galor, O., and J. Zeira. 1993. "Income Distribution and Macroeconomics." Review of Economic Studies 60, no. 1: 35-52.

Giannetti, M., and S. Ongena. 2005. "Financial Integration and Entrepreneurial Activity: Evidence from Foreign Bank Entry in Emerging Markets.” Finance Working Paper no. 091/2005, European Corporate Governance Institute, Brussels. 
Guzman, M.G. 2000. "Bank Structure, Capital Accumulation, and Growth: A Simple Macroeconomic Model." Economic Theory 16, no. 2: 421-455.

Heggestad, A.A., and S.A. Rhoades. 1978. "Multi-Market Interdependence and Local Market Competition in Banking." Review of Economics and Statistics 60, no. 4: 523-532.

Hill, C.W.L. 1990. "Cooperation, Opportunism, and the Invisible Hand: Implications for Transaction Cost Theory." Academy of Management Review 15, no. 3: 500-513.

Honohan, P. 2004. "Financial Development, Growth, and Poverty: How Close Are the Links?" World Bank Policy Research Working Paper no. 3203, Washington, DC.

Jeon, B.N.; M.P. Olivero; and J. Wu. 2011. "Do Foreign Banks Increase Competition? Evidence from Emerging Asian and Latin American Banking Markets." Journal of Banking \& Finance 35, no. 4: 856-875.

Kilinç, M.; Z. Kilinç; and M.I. Turhan. 2012. "Resilience of the Turkish Economy During the Global Financial Crisis of 2008." Emerging Markets Finance \& Trade 48, supp. 5: 19-34.

Kim, Y.S., and I. Mathur. 2008. "The Impact of Geographic Diversification on Firm Performance." International Review of Financial Analysis 17, no. 4: 747-766.

King, R.G., and R. Levine. 1993. "Finance and Growth: Schumpeter Might Be Right.” Quarterly Journal of Economics 108, no. 3: 717-737.

Laeven, L., and F. Valencia. 2012. "The Use of Blanket Guarantees in Banking Crises." Journal of International Money and Finance 31, no. 5: 1220-1248.

La Porta, R.; F. López-de-Silanes; and A. Shleifer. 2002. "Government Ownership of Banks." Journal of Finance 57, no. 1: 265-301.

Levine, R. 1997. "Financial Development and Economic Growth: Views and Agenda." Journal of Economic Literature 35, no. 2: 688-726.

Maddala, G.S., and S. Wu. 1999. "A Comparative Study of Unit Root Tests with Panel Data and a New Simple Test." Oxford Bulletin of Economics and Statistics 61, supp. 1: 631-652.

Maurer, N., and S. Haber. 2007. "Related Lending and Economic Performance: Evidence from Mexico." Journal of Economic History 67, no. 3: 551-581.

Megginson, W.L. 2005a. The Financial Economics of Privatization. New York: Oxford University Press. 2005b. "The Economics of Bank Privatization." Journal of Banking \& Finance 29, nos. 8-9: 1931-1980.

Mester, L.J. 1987. "Multiple Market Contact Between Savings and Loans: Note.” Journal of Money, Credit and Banking 19, no. 4: 538-549.

— 1992. "Perpetual Signalling with Imperfectly Correlated Costs." Rand Journal of Economics 23, no. 4: 548-563.

Mester, L.J.; L.I. Nakamura; and M. Renault. 2007. "Transactions Accounts and Loan Monitoring." Review of Financial Studies 20, no. 3: 529-556.

Mian, A. 2006. "Distance Constraints: The Limits of Foreign Lending in Poor Economies." Journal of Finance 61, no. 3: 1465-1505.

Önder, Z., and S. Özyildirim. 2010. "Banks, Regional Development Disparity and Growth: Evidence from Turkey." Cambridge Journal of Economics 34, no. 6: 975-1000.

. 2011. "Political Connection, Bank Credits and Growth: Evidence from Turkey." World Economy 34, no. 6: 1042-1065.

Özyildirim S., and Z. Önder. 2008. "Banking Activities and Local Output Growth: Does Distance from Centre Matter?" Regional Studies 42, no. 2: 229-244.

Pagano, M. 1993. "Financial Markets and Growth: An Overview." European Economic Review 37, nos. 2-3: 613-622.

Park, K., and G. Pennacchi. 2009. "Harming Depositors and Helping Borrowers: The Disparate Impact of Bank Consolidation." Review of Financial Studies 22, no. 1: 1-40.

Peachey, S., and A. Roe. 2006. "Access to Finance, Measuring the Contribution of Savings Banks." Working Paper, World Savings Banks Institute, Brussels.

Petersen, M.A., and R.G. Rajan. 1995. "The Effect of Credit Market Competition on Lending Relationships." Quarterly Journal of Economics 110, no. 2: 405-443.

Rajan, R.G., and L. Zingales. 1998. "Financial Dependence and Growth." American Economic Review 88, no. 3: 559-586.

. 2003. Saving Capitalism from the Capitalists. New York: Crown Business Division of Random House. 
Rosen, R.J. 2007. "Bank Market Conditions and Deposit Interest Rates." Journal of Banking \& Finance 31, no. 12: 3862-3884.

Saeed, A., and O. Vincent. 2012. "Bank Concentration and Firm Investment: Empirical Evidence from India." Emerging Markets Finance \& Trade 48, no. 3: 85-105.

Sapienza, P. 2004. "The Effects of Government Ownership on Bank Lending." Journal of Financial Economics 72, no. 2: 357-384.

Schaffer, M.E., and S. Stillman. 2011. "XTOVERID: Stata Module to Calculate Tests of Overidentifying Restrictions After xtreg, xtivreg, xtivreg2, xthtaylor." Statistical Software Components S456779, Boston College Department of Economics, revised November 2.

Stiglitz, J.E., and A. Weiss. 1981. "Credit Rationing in Markets with Imperfect Information." American Economic Review 71, no. 3: 393-410.

Tanyeri, B. 2010. "Financial Transparency and Sources of Hidden Capital in Turkish Banks." Journal of Financial Services Research 37, no. 1: 25-43.

Udell, G.F. 2004. Asset-Based Finance. New York: Commercial Finance Association.

Yafeh, Y., and O. Yosha. 2001. "Industrial Organization of Financial Systems and Strategic Use of Relationship Banking." European Finance Review 5, nos. 1-2: 63-78.

Zarutskie, R. 2006. "Evidence on the Effects of Bank Competition on Firm Borrowing and Investment." Journal of Financial Economics 81, no. 3: 503-537. 
Copyright of Emerging Markets Finance \& Trade is the property of M.E. Sharpe Inc. and its content may not be copied or emailed to multiple sites or posted to a listserv without the copyright holder's express written permission. However, users may print, download, or email articles for individual use. 